\title{
RJEČNIK HRVATSKIH ANIMALISTIČKIH FRAZEMA
}

Ivana Vidović Bolt, Branka Barčot, Željka Fink-Arsovski, Barbara Kovačević, Neda Pintarić, Ana Vasung (2017). Rječnik hrvatskih animalističkih frazema. Zagreb: Školska knjiga. ISBN: 978-953-0-40044-3, trda vezava, 244 strani, 159,00 kn.

Pri založbi Školska knjiga je leta 2017 izšel frazeološki slovar Rječnik hrvatskih animalističkih frazema avtoric Ivane Vidović Bolt, Branke Barčot, Željke Fink-Arsovski, Barbare Kovačević, Nede Pintarić in Ane Vasung. Kot je zapisano na spletni strani založbe Školska knjiga, je slovar plod znanstvenega dela frazeologinj, ki se ukvarjajo s frazeologijo v različnih slovanskih jezikih (med njimi so hrvaščina, poljščina, ruščina in bolgarščina) in del raziskave živalskih izrazov v slovanskih jezikih pod vodstom prof. dr. Ivane Vidović Bolt.

Ko govorimo o frazeologiji, govorimo o frazeoloških enotah z večbesedno jezikovno zgradbo, ki s svojo ekspresivnostjo izkazujejo tudi pomensko celovitost. Ko govorimo o frazeološkem slovarju, se porodijo makro- in mikrostrukturna vprašanja, ki zadevajo osnovne vidike: katere frazeološke enote so zajete v slovar, koliko frazeoloških enot ponuja slovar in kako so frazeološke enote prikazane v slovarju, da bo zadoščeno pričakovanjem ter potrebam slovarskih uporabnikov. Ko govorimo o frazeološkem slovarju Rječnik hrvatskih animalističkih frazema, govorimo o novem zavidljivem podvigu zagrebške frazeološke šole, saj slovar ponuja pester izbor in izčrpno obdelavo bogatega gradiva.

Slovar, ki obsega 244 strani, je vsebinsko razdeljen na več delov. Po predgovoru (4 strani) sledijo osnovna navodila za branje slovarja (13 strani) ter slovar hrvaške zoonimske frazeologije, ki predstavlja vsebinsko jedro knjige (185 strani). V kazalu frazemov so po abecednem redu našteti vsi obravnavani frazemi (25 strani). Knjiga se končuje s seznamom literature znanstvenih in strokovnih del s področja frazeologije, frazeografije in leksikografije (2 strani) in seznamom virov za ilustrativno gradivo.

$\mathrm{V}$ navodilih avtorice pojasnijo dvojno pojmovanje frazeologije kot jezikoslovno disciplino, ki obravnava frazeme in kot zbirko frazemov, ki glede na različne kriterije tvorijo posebne frazeološke skupine. Tako lahko z ozirom na skupne sestavine z različnih 
pomenskih polj ločimo med somatsko, fitonimno ali zoonimno frazeologijo. Slednja skupina predstavlja jezikovno gradivo za slovar Rječnik hrvatskih animalističkih frazema, v katerem je obdelanih okoli 1400 ustaljenih frazeoloških enot, ki imajo v svoji sestavinski zgradbi (vsaj) eno sestavino, s katero je mogoče frazeološko enoto povezati z živalskim svetom. V animalistično frazeologijo sodijo torej frazemi, ki imajo v sestavinski zgradbi zoonim oz. zoonimne sestavine (npr. MUHA v dosadan kao muha), frazemi z zoonimno pridevniško izpeljanko, (npr. KOKOŠJI v frazemu kokošja pamet) ter zoonimno ali živalsko somatsko sestavino (PERO v lak (lagan) kao pero). V izjemno zanimivi četrti skupini so obdelani frazemi s sestavinami iz živalskega sveta kot so različne priprave in predmeti (UZDA v držati na uzdi $\boldsymbol{k o g a}$, što), habitat (DŽUNGLA v zakon džungle), bivališče (BRLOG v živjeti $<\mathbf{k a 0}>\mathbf{u}$ brlogu) in druge, kot na primer mrhovina, nepredelani živalski izdelki ali glagoli, ki so povezani z živalmi in onomatopoetični izrazi.

Avtorice so se odločile za frazeološke enote tako v širšem kot tudi v ožjem smislu. V slovarju so zbrane leksikalizirane stalne zveze, ki so vsaj deloma idiomatične in so dosegle določeno stopnjo desemantičnosti (dobiti mlade) in tudi terminološke zveze iz strokovnih pojmovanj, torej leksikalizirane stalne zveze, ki jih ne odlikuje posebna ekspresivnost (ptičja gripa). Glede na različne strukturne vrste frazeoloških enot so v slovarju predstavljeni besednozvezni frazemi, ki so sestavljeni iz polnopomenske in nepolnopomenske besede, glagolske, samostalniške ali pridevniške besedne zveze. Zelo pogosti so primerjalni oz. komparativni frazemi, pri katerih frazemi glede na strukturni vidik sestavljajo dve skupini: skupino trodelnih $(\mathrm{A}+\mathrm{B}+\mathrm{C})$ in skupino dvodelnih $(\mathrm{B}+\mathrm{C})$. Pri trodelnih primerjalnih frazemih lahko del $C$ sestavlja več besed (vrtjeti se (meškoljiti se i sl.) kao piškor u loncu), pri dvodelnih lahko tudi manjka del A (kao pas na lancu). Stavčnih frazemov ne navajajo $\mathrm{z}$ veliko začetnico, in način zapisovanja potrjujejo v ilustrativnem gradivu, npr. <i> vuk sit i ovce na broju v zgledu „Kako smo mi površinski mala zemlja, teško je to sve skupa uskladiti da bude i vuk sit i ovce na broju.“ (Str. 198) Pri zapisovanju dvojčičev (zakukuljeno i zamumuljeno) se držijo jezikovnega merila, saj vključujejo tudi tvorjenke tipa zakukuljeno-zamumuljeno. Animalistični frazemi so najpogosteje odraz antopocentrizma $\mathrm{v}$ jeziku in negativno konotirani. Nekateri frazemi vsebujejo sestavine, ki niso zgolj del živalskega sveta, vendar je slikovitost, ki jo izražajo, močno povezana z živalskim svetom (držati glavu u pesku, gledati u zube). Pogled v preteklost pripelje do zanimivega spoznanja, da številni animalistični frazemi izvirajo iz mitologije ali biblije (žrtveni jarac, zlatno tele). Pogled v sedanjost odkriva, kako poteka proces frazeologizacije, na primer besedna zveza modni mačak. V slovarskem gradivu najdemo tudi frazeme s determinologiziranimi sestavinami, pri katerih je prišlo do procesa prehajanja strokovnega izrazja v splošni jezik (stati na kurje oko komu).

Slovar je oblikovno in vsebinsko že na prvi pogled bralcu zelo prijazen. V poglavju o osnovnih napotkih za branje slovarja so predstavljeni slovarski članki, ki vsebujejo: nadiztočnice, frazem $\mathrm{v}$ iztočnici $\mathrm{v}$ imenovalniški in edninski obliki, pomenski opis in ponazarjalni zgled $\mathrm{v}$ sobesedilu. Nadiztočnice, ki so glavne sestavine frazema, so: 
,jednorječnice, polusloženice, višerječni nazivi“ in so razvrščene abecedno po naslednji hierarhiji: zoonim (SLON), pridevniška izpeljanka (PASJI), zoosomatska sestavina (ŠKRGE) in ostale sestavine, ki so povezane z živalskim svetom. Če je v sestavi frazema več frazemskih iztočnic, so razporejene po abecednem redu prve sestavine, pod vsemi iztočnicami so napotki, kje lahko najdemo podrobni slovarski članek. Slovarski članek odlikujejo premišljeno izbrana oblikovna sredstva kot so različne vrste pisave, različni oklepaji in različni znaki, s katerimi so podane določene oznake, na primer zvrstne, stilne in pragmatične. Frazemski iztočnici sledi pomenski opis ali definicija in primer uporabe v sobesedilu oziroma ponazarjalni zgled. Ilustrativno gradivo so avtorice izpisovale iz hrvaških umetnostnih besedil, spletnih korpusov, različnih tiskanih medijev in spletnih iskalnikov Google in Yahoo. Pohvaliti velja odločitev avtoric, da so sistematični in pregledni nabor animalističnih frazemov iz navedene znanstvene in strokovne literature kot so enojezični ter dvojezični slovarji, vzporedno preverili v različnih anketah med govorci hrvaškega jezika na terenu, tudi med starejšimi osebami v domovih.

Naj zaključim s povzetkom: Slovar je napisan z znanjem, pregledno, smelo zasnovano, z jasnim konceptom, prodorno in predvsem uporabno. Poznavalcem bo služil kot strokovna knjiga in prinesel veliko novega, radovednim bralcem pa bo nedvomno odprl pogled v frazeološki svet. Rječnik hrvatskih animalističkih frazema je zgleden dosežek timskega dela zagrebške frazeološke šole, ki vedno znova navdušuje s svojimi izjemnimi projekti. 